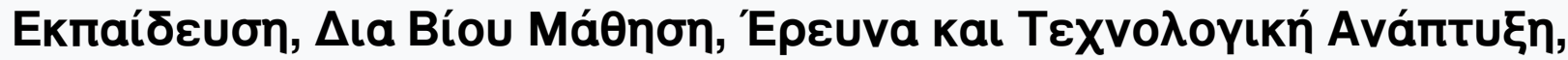 Katvotopía Kal Oıкоvopía
}

Tóp. 1 (2016)

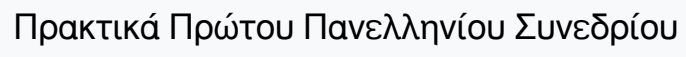

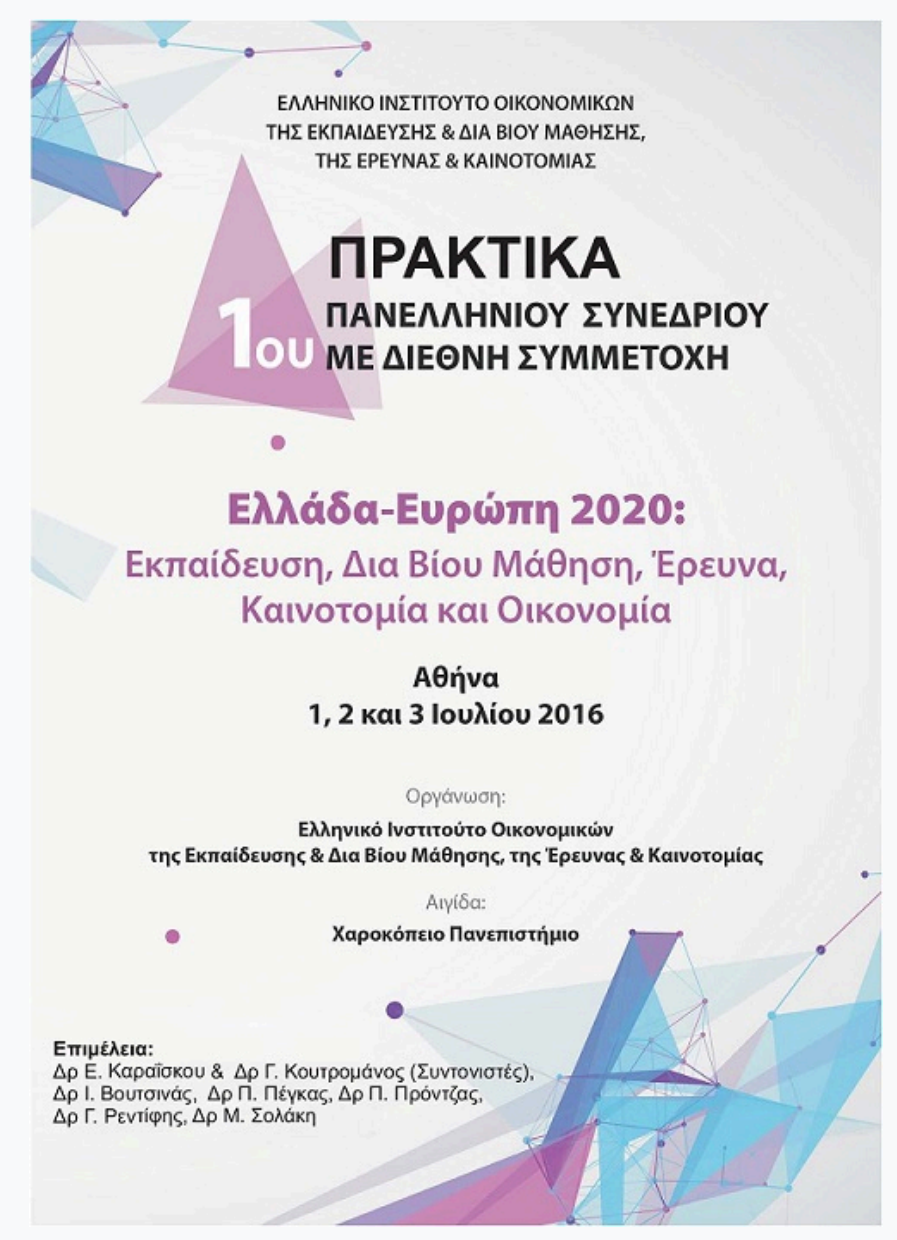

Human Capital and Economic Growth: A Case Study of Greece before Economic Crisis

Theocharoula Magoula

doi: $\underline{10.12681 / \text { elrie.795 }}$ 


\title{
Human Capital and Economic Growth: A Case Study of Greece before Economic Crisis
}

\author{
Theocharoula Magoula \\ magoul@econ.uoa.gr
}

\begin{abstract}
Пєрі́ $\lambda \psi \psi \eta$

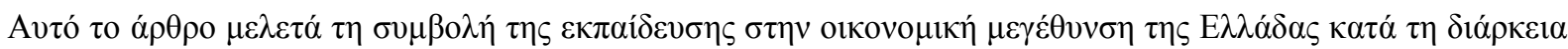

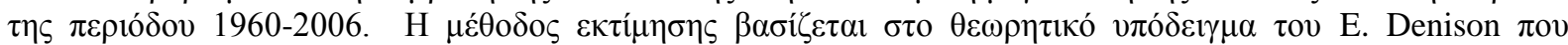

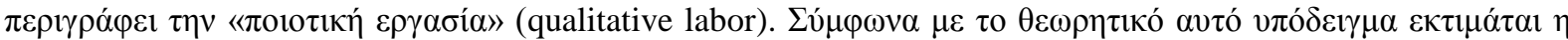

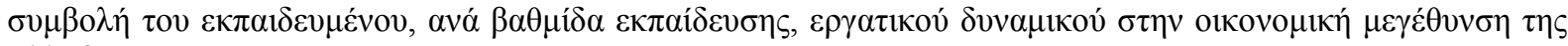
E $\lambda \lambda \dot{\alpha} \delta \alpha \varsigma$.

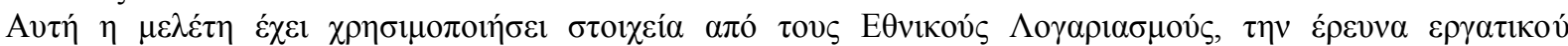

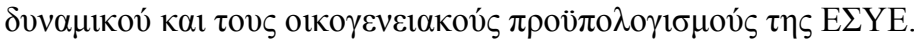

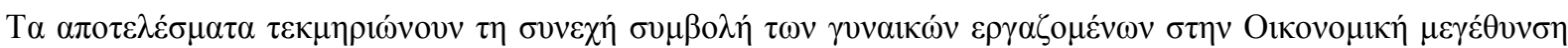

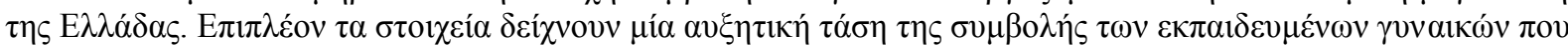

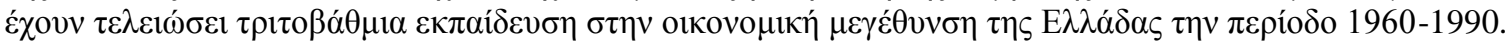

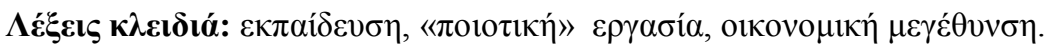

\begin{abstract}
This paper investigates the contribution of education to the economic growth of Greece during the period 19602006, before the 2008 crisis. The method is based on "qualitative labor " approach of E. Denison. It estimates the contribution of different levels skills to the economic growth of Greece.

The study utilizes data from the National Accounts, the Labor Force Surveys and the Household Budget Surveys of the National Statistical Service of Greece.

The results suggest that the relative contribution of secondary and higher education to economic growth has risen. The findings also indicate that the increased number of women with higher education and their subsequent participation in the labor force have contributed significantly to the growth process.
\end{abstract}

Keywords: education, quality labor, economic growth

\section{Introduction}

The impact of education on economic growth has been dealt with in numerous works over the last fifty years. In their classic contributions, Schultz (1961) and Denison (1962) have strived to explain the rate of technological change by assigning qualitative attributes to the traditional factors of production and adjusting accordingly both the capital and labour inputs.

Lucas (1990) explains that physical capital fails to flow to poor countries because of their poor endowments of complementary human capital. This point is confirmed from an aggregate cross-country empirical analysis by Benhabib and Spiegel (1994). At this point, two stylized facts are of interest: (a) Economies with a larger stock of human capital experience faster growth (Romer 1990); and (b) Investing in schooling is a prerequisite to the creation of 
human capital which, in turn, generates ideas and is capable of developing new products (Romer 1993).

Besides health, education is the most important investment activity in human capital theory (Romer 1993), for it enhances human abilities in several ways. The most obvious effect of formal schooling is the development of vocational skills which are useful in the future labour market (Choi 1993). Formal schooling, in conjunction with general and liberal arts education, can also increase the efficiency with which new skills are acquired in the labour market (Blau 1996 and the literature cited therein).The presumption is that an educated labour force, relative to a non-educated one, has a comparative advantage with respect to learning, creating, implementing, and adopting new technologies, thereby generating growth (Benhabib and Spiegel 1994).

Ceteris paribus, higher levels of education may permit workers to accomplish more with the resources at hand (the marginal product of education is higher than otherwise); to accumulate more human capital on the job than less educated workers; and to enhance their 'entrepreneurial' ability (Welch 1970, Choi 1993). However, investment in education implies foregone labour earnings on the part of the persons involved. And foregone earnings vary with the level of human capital invested. That is, a worker with little (much) human capital foregoes a lower (higher) wage in order to accumulate more human capital (Mankiw et al. 1992). In terms of measurement, and regardless of shortcomings, the average number of years in school of the labour force has been used as a good proxy for human capital in the new growth literature (Mankiw et al 1992, Mulligan and Sala-i-Martin 1995).

The positive impact of education on economic growth has been confirmed in several empirical studies. Among the most interesting contributions are Winter-Ebmer (1992) for Israel; the World Bank (1993) for Hong-Kong, Indonesia, Japan, Korea, Malaysia, Taiwan, Singapore and Thailand; Juoro (1993) for Malaysia; and Chatterji (1998).

Almost all of the empirical theories refer to comparative outcomes from different countries and face serious problems of availability of data. Generally, the problem that arises from these models is the difficulty in empirical testing.

The conclusions that can be drawn from the empirical studies are: There is a (highly) positive correlation between education and economic growth. It is impossible to accurately estimate the contribution of education to economic growth using the contemporary theories of endogenous economic growth.

So, the main reason for the success of the "traditional" models based on the classic theory of economic growth is their capability of organising data. It should be noted that the endogenous growth models cannot be described in a clear empirical framework. Therefore, the models which are most effective in estimating the contribution of education to economic growth are those compatible with Denison's approach.

In this paper we estimate the contribution of education to the economic growth of Greece in the 1961-2006 period according to the Denison' s approach of 'qualitative labor'.

\section{Methodology}

As already mentioned, the methodology we use is compatible to the Denison's approach which refers to quality labor. Basic element of the aforementioned approach is the distinction between three levels of education of the workforce, particularly of the employed. Thus, the production function is the following: 


$$
Y^{*}=f\left(K, L_{1}, L_{E}\right)
$$

where $L_{1}$ stands for the number of employed who have completed compulsory education and $L_{E}$ stands for the number of employed who have completed secondary or higher education. Thus:

$$
L_{E}=\sum_{i=2}^{3} L_{i}
$$

Based on the above, it becomes evident that the total of employed is:

$$
L=\sum_{i=2}^{3} L_{i}+L_{1}
$$

Therefore, the economic growth equation becomes:

$$
\frac{\partial Y^{*}}{\partial t}=\frac{\partial K}{\partial t} f_{K}+\frac{\partial L_{1}}{\partial t} f_{L_{1}}+\frac{\partial L_{E}}{\partial t} f_{L_{E}}+R
$$

Given the fact that the marginal product of a certain level of education is equal to the difference in the average salary from the previous level due to the extra education, equation (2) becomes:

$$
\frac{\partial Y^{*}}{\partial t}=\frac{\partial K}{\partial t} f_{K}+\frac{\partial L_{1}}{\partial t} f_{L_{1}}+\sum_{i=2}^{3} \frac{\partial L_{i}}{\partial t}\left(\bar{W}_{i}-\bar{W}_{i-1}\right)+R
$$

From equation (3) and taking into account that everybody is obliged by law to complete compulsory education, it can be concluded that the employed who have completed secondary or higher education, that is post-compulsory education, contribute to the production of quality labor.

Within the framework of this analysis, and assuming that there will be no changes in those employed having completed compulsory education, the contribution of educated employed becomes as follows:

$$
\sum_{i=2}^{3} \frac{1}{L} \frac{\partial L_{i}}{\partial t}\left(\bar{W}_{i}-\bar{W}_{i-1}\right) \frac{L}{Y^{*}}=\sum_{i=2}^{3} \frac{\partial L_{i}}{\partial t} \frac{\left(\bar{W}_{i}-\bar{W}_{i-1}\right)}{Y^{*}}
$$

In other words, the contribution of education to economic growth is equal to the increase in the extra educated employed (in each level of education) times the difference in average salary from the previous level due to the extra education.

Hence, the equation of the rate of economic growth becomes:

$$
g_{Y^{*}}=\frac{1}{Y^{*}} \frac{\partial K}{\partial t} f_{K}+\frac{1}{Y^{*}} \frac{1}{L} \frac{\partial L_{1}}{\partial t} \frac{\partial f}{\partial L_{1}} \frac{L}{1}+\sum_{i=2}^{3} \frac{\partial L_{i}}{\partial t} \frac{1}{L} \frac{\left(\bar{W}_{i}-\bar{W}_{i-1}\right) L}{Y^{*}}+R
$$

Or, to put it more simply:

$$
g_{Y^{*}}=\frac{1}{Y^{*}} \frac{\partial K}{\partial t} f_{K}+\left(g_{L_{1}} s_{L_{1}}\right)+\sum_{i=2}^{3} g_{L_{i}} s_{L_{i}}+R
$$

Therefore, the contribution of education to the growth rate of GDP, according to the methodology used, is equal to the product of the growth rate of employment of of secondary and higher education graduates times their corresponding income share in GDP. 


\section{Empirical Evidence}

As mentioned before, the purpose of this study is to investigate the contribution of education to economic growth of Greece the period before global financial crisis. So that the following table describes the employment by level of education and sex up to 2006.

The global financial crisis of 2007-2008 had a severe impact on Greece which changed completely the data of Greek employment. The youth unemployment, especially among the highly skilled have tremendous increased after 2006 ( Labrianides \& Sykas, 2015).

Table 1: Employment (15 years and over) by education level and sex (In thousands)

\begin{tabular}{|c|c|c|c|c|c|c|c|c|c|c|c|c|c|}
\hline $\begin{array}{l}\text { GREECE, } \\
\text { TOTAL }\end{array}$ & 1994 & 1995 & 1996 & 1997 & 1998 & 1999 & 2000 & 2001 & 2002 & 2003 & 2004 & 2005 & 2006 \\
\hline Males & \multicolumn{13}{|c|}{$2.373,52.365,62.371,92.342,22.443,52.535,72.558,32.566,52.608,72.652,62.668,52.695,72.715,7$} \\
\hline $\begin{array}{l}\text { Higher } \\
\text { Education }\end{array}$ & 374,1 & 380,0 & 408,1 & 410,4 & 451,8 & 607,4 & 630,8 & 628,9 & 644,9 & 680,6 & 799,0 & 782,3 & 813,9 \\
\hline $\begin{array}{l}\text { Secondary } \\
\text { Education }\end{array}$ & 633,9 & 643,3 & 654,6 & 665,7 & 730,9 & 756,6 & 764,7 & 782,5 & 839,4 & 862,5 & 856,3 & 899,7 & 927,0 \\
\hline Primary & \multicolumn{13}{|c|}{$1.365,51.342,21.309,21.266,11.260,81.171,71.162,81.155,11.124,41.109,51.013,21.013,6974,7$} \\
\hline Education & & & & & & & & & & & & & \\
\hline Females & \multicolumn{13}{|c|}{$1.279,61.302,91.314,41.330,01.352,81.465,51.498,21.504,81.550,61.604,51.638,11.667,01.718,4$} \\
\hline & & & & & & & & & & & & & \\
\hline $\begin{array}{l}\text { Higher } \\
\text { Education }\end{array}$ & 249,8 & 260,5 & 276,2 & 290,6 & 329,8 & 481,4 & 505,3 & 507,2 & 528,6 & 575,4 & 644,1 & 662,3 & 718,1 \\
\hline $\begin{array}{l}\text { Secondary } \\
\text { Education }\end{array}$ & 348,8 & 373,8 & 370,4 & 387,3 & 403,7 & 410,2 & 429,1 & 445,5 & 464,1 & 480,7 & 500,3 & 509,7 & 519,0 \\
\hline $\begin{array}{l}\text { Primary } \\
\text { Education }\end{array}$ & 681,1 & 668,5 & 667,7 & 652,1 & 619,3 & 573,9 & 563,8 & 552,1 & 557,9 & 548,5 & 493,7 & 494,9 & 481,2 \\
\hline
\end{tabular}

Source:ESYE.

Categorization of education level in table 1 was based on the following:

\begin{tabular}{ll}
\hline Our Categorization & $\begin{array}{l}\text { ESYE categorization for the years 1994-2001 } \\
\text { (according table 2) }\end{array}$ \\
\hline Higher education & $\begin{array}{l}\text { Category 1 (University degree or post graduate } \\
\text { degree) }\end{array}$ \\
\hline Secondary education & Category 2 (Completed secondary education) \\
\hline Primary education & $\begin{array}{l}\text { Category 3 (None - completed 3 years of the 6 years } \\
\text { secondary education) }\end{array}$ \\
\hline
\end{tabular}

This categorization of data in table 1 was chosen in order to be compatible with the one used by ESYE in table 2. Table 2 indicates the change, by level of education, of labour force of Greece in period 1994-2006. 
Table 2: Annual Change in Employment (15 years and over) by education level and sex (In thousands)

\begin{tabular}{|c|c|c|c|c|c|c|c|c|c|c|c|c|}
\hline $\begin{array}{l}\text { GREECE, } \\
\text { TOTAL }\end{array}$ & 1995 & 1996 & 1997 & 1998 & 1999 & 2000 & 2001 & 2002 & 2003 & 2004 & 2005 & 2006 \\
\hline \multicolumn{13}{|l|}{ Males } \\
\hline $\begin{array}{l}\text { Higher } \\
\text { Education }\end{array}$ & 6,0 & 28,1 & 2,3 & 41,4 & 155,6 & 23,4 & $-1,9$ & 16,0 & 35,7 & 118,4 & $-16,7$ & 31,6 \\
\hline $\begin{array}{l}\text { Secondary } \\
\text { Education }\end{array}$ & 9,4 & 11,3 & 11,1 & 65,1 & 25,7 & 8,1 & 17,8 & 56,9 & 23,1 & $-6,2$ & 43,4 & 27,3 \\
\hline $\begin{array}{l}\text { Primary } \\
\text { Education }\end{array}$ & $-23,3$ & $-33,0$ & $-43,2$ & $-5,2$ & $-89,1$ & $-8,9$ & $-7,7$ & $-30,7$ & $-14,9$ & $-96,3$ & 0,4 & $-38,9$ \\
\hline \multicolumn{13}{|l|}{ Females } \\
\hline $\begin{array}{l}\text { Higher } \\
\text { Education }\end{array}$ & 10,8 & 15,7 & 14,4 & 39,2 & 151,6 & 23,9 & 1,9 & 21,4 & 46,8 & 68,7 & 18,2 & 55,8 \\
\hline $\begin{array}{l}\text { Secondary } \\
\text { Education }\end{array}$ & 25,1 & $-3,4$ & 16,9 & 16,4 & 6,5 & 18,9 & 16,4 & 18,6 & 16,6 & 19,6 & 9,4 & 9,3 \\
\hline $\begin{array}{l}\text { Primary } \\
\text { Education }\end{array}$ & $-12,5$ & $-0,8$ & $-15,6$ & $-32,8$ & $-45,4$ & $-10,1$ & $-11,7$ & 5,8 & $-9,4$ & $-54,8$ & 1,2 & $-13,7$ \\
\hline
\end{tabular}

\section{Source ESYE.}

Table 3: Annual Salary by level of education and sex in Euro (2005 prices)

\begin{tabular}{|c|c|c|c|c|c|c|c|c|c|c|c|c|}
\hline $\begin{array}{l}\text { GREECE, } \\
\text { TOTAL }\end{array}$ & 1994 & 1995 & 1996 & 1997 & 1998 & 1999 & 2000 & 2001 & 2003 & 2004 & 2005 & 2006 \\
\hline Males & & & & & & & & & & & & \\
\hline $\begin{array}{l}\text { Higher } \\
\text { Education } \\
\text { Elat }\end{array}$ & $8.409,40$ & $8.390,42$ & $8.546,13$ & $9.563,44$ & $9.769,23$ & $9.651,28$ & $39.838,57$ & $10.123,4$ & $+10.652,4$ & $410.813,7$ & $711.076,2$ & $211.164,2$ \\
\hline $\begin{array}{l}\text { Secondary } \\
\text { Education } \\
\end{array}$ & $4.814,35$ & $5.030,51$ & $4.890,13$ & $5.233,28$ & $4.875,14$ & $4.709,62$ & $5.006,98$ & $5.366,61$ & $5.513,64$ & $46.021,03$ & $6.011,97$ & $75.994,72$ \\
\hline $\begin{array}{l}\text { Primary } \\
\text { Education } \\
\end{array}$ & \begin{tabular}{|l}
$2.477,74$ \\
\end{tabular} & $2.450,39$ & $2.280,80$ & $2.401,39$ & $2.422,72$ & $2.437,17$ & $2.350,17$ & $2.284,68$ & $2.686,11$ & $12.866,57$ & $2.936,12$ & $2.877,48$ \\
\hline Females & & & & & & & & & & & & \\
\hline $\begin{array}{l}\text { Higher } \\
\text { Education } \\
\end{array}$ & $5.088,97$ & $5.013,35$ & $5.270,04$ & $6.092,54$ & $6.851,25$ & $6.961,64$ & $47.045,13$ & $7.398,38$ & $8.624,70$ & & $58.905,07$ & $78.903,7$ \\
\hline $\begin{array}{l}\text { Secondary } \\
\text { Education } \\
\end{array}$ & $\begin{array}{r}1.976,00 \\
\end{array}$ & $2.017,29$ & $1.984,65$ & $2.188,10$ & $2.513,20$ & $2.243,99$ & $2.386,21$ & $2.560,30$ & $3.046,98$ & $8: 3.160,42$ & $3.114,89$ & $3.069,14$ \\
\hline $\begin{array}{l}\text { Primary } \\
\text { Education }\end{array}$ & 646,41 & 706,21 & 624,11 & 612,58 & 657,06 & 567,27 & 613,07 & 625,02 & 731,68 & 756,59 & 773,20 & 782,94 \\
\hline
\end{tabular}

Source Labor Force Surveys, ESYE

According to these findings, the number of labour force with education until primary education has declined.

It is mentioning that, National Statistics Services of Greece (ESYE) uses for fist time in 1999, a new system for data classification and because of this it is noted higher change of labour force.

It is noted that the annual salary by level of education and sex is used as estimation for the marginal product by level of education and sex.

From the data of the above table it becomes obvious that mean wages of labour force of women of the every level of education are lower from the mean wages of corresponding level of education of men. 
Table 4:Difference in Annual Salary between level of education in Euro (2005 prices)

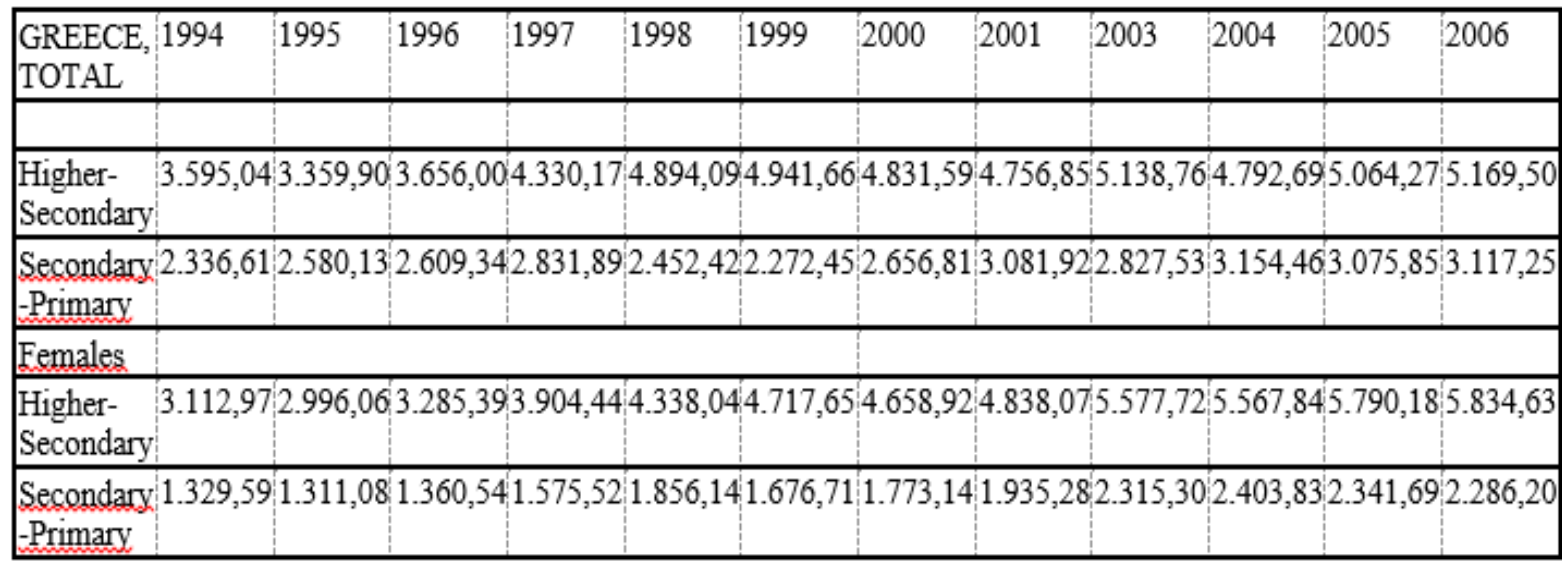

Source: Labor Force Surveys, ESYE

The rising through time wage differentiation among workers with different educational background has inevitably contributed to the rising role of secondary and higher education to the economic growth of Greece.

Table 5: GDP factor prices in 2005 prices (In million Euro)

\begin{tabular}{|l|l|l|l|l|l|l|l|l|l|l|l|l|l|l|}
\hline $\begin{array}{l}\text { GREECE, } \\
\text { TOTAL }\end{array}$ & 1994 & 1995 & 1996 & 1997 & 1998 & 1999 & 2000 & 2001 & 2002 & 2003 & 2004 & 2005 & 2006 \\
\hline $\begin{array}{l}\text { GDP, 2005 } \\
\text { prices }\end{array}$ & 111.420 & 113.887 & 116.207 & 119.210 & 122.546 & 125.559 & 142.255 & 147.169 & 153.604 & 162.591 & 171.651 & 178.017 & 184.210 \\
\hline $\begin{array}{l}\text { dGDP } \\
\text { (Annual } \\
\text { Change }\end{array}$ & & $2.466,4$ & $2.319,6$ & $3.003,5$ & $3.335,7$ & $3.013,0$ & 16.695 & $4.914,7$ & $6.434,7$ & $8.986,8$ & $9.060,5$ & $6.365,2$ & $6.193,7$ \\
\hline$\%$ Change & & & & & & & 8 & & & & & & \\
\hline
\end{tabular}

Source ESYE, Gross Domestic Product in factor prices in 2005 prices.

Calculation of Gross Domestic Product in factor prices in 2005 prices is based on Gross Domestic Product in factor prices in current prices (ESYE) and the Consumer Price Index (ESYE). For the years 2000-2007, Gross Domestic Product in factor prices in current prices are estimated values by ESYE.

The following table describes the contribution of education by sex or regardless sex during the decades 1961-1971, 1971-1981 and 1981-1991. It is noted that g means GDP growth rate.

Table 6.a. Contribution of education to economic growth by sex (period 1961-1991)

\begin{tabular}{|c|c|c|c|c|c|c|c|c|c|c|c|c|c|}
\hline \multirow{2}{*}{$\begin{array}{l}\text { periods } \\
1961-71\end{array}$} & \multirow{2}{*}{$\begin{array}{c}\mathrm{g} \\
8.00\end{array}$} & \multirow{2}{*}{$\begin{array}{l}\text { total } \\
0.16\end{array}$} & \multicolumn{3}{|c|}{$\frac{\text { regardless of sex }}{1 \text { ary } 2 \text { ary higher }}$} & \multicolumn{4}{|c|}{ total 1ary 2ary higher } & \multicolumn{4}{|c|}{ total 1 ary 2ary higher } \\
\hline & & & 0.06 & 0.06 & 0.04 & 0.12 & 0.05 & 0.04 & 0.03 & 0.04 & 0.01 & 0.02 & 0.012 \\
\hline $1971-81$ & 3.40 & 1.03 & 0.53 & 0.26 & 0.24 & 0.52 & 0.24 & 0.15 & 0.14 & 0.51 & 0.29 & 0.12 & 0.10 \\
\hline $1981-91$ & 0.80 & 2.25 & 0.11 & 1.38 & 0.76 & 1.25 & -0.01 & 0.88 & 0.38 & 1.00 & 0.12 & 0.50 & 0.38 \\
\hline
\end{tabular}

Source: Th. Magoula (1998), Th. Magoula and K. Prodromidis (1999)

According to the data of the above table, the role of primary education has declined in the 1980s relative to that of secondary education, which has contributed the most to economic growth of Greece. The results concerning the insignificant contribution of education to Greece's economic growth in the sixties is comparable to the respective findings of earlier studies by Leibenstein (1967), Bowles (1967). Because of the rising participation of women in the labour force their contribution per education level in the growth process has become 
more comparable to that of men, since the seventies. In the eighties, women of higher education have contributed about as much as men in economic growth.

The following table 6.b describes the calculation of contribution to economic growth by level of education and sex from 1994 to 2007 (except 2002, 2007 where there is no data available).

Table 6.b: contribution to economic growth by level of education and sex (period 1994-2006)

\begin{tabular}{|c|c|c|c|c|c|c|c|c|c|c|c|}
\hline $\begin{array}{l}\text { GREECE, } \\
\text { TOTAL }\end{array}$ & 1995 & 1996 & 1997 & 1998 & 1999 & 2000 & 2001 & 2003 & 2004 & 2005 & 2006 \\
\hline \multicolumn{12}{|l|}{ Males } \\
\hline $\begin{array}{l}\text { Higher } \\
\text { Education }\end{array}$ & 0,01756 & 0,08828 & 0,00831 & 0,16532 & 0,61246 & 0,07948 & $-0,00614$ & 0,11268 & 0,33072 & $-0,04749$ & 0,08875 \\
\hline $\begin{array}{l}\text { Secondary } \\
\text { Education }\end{array}$ & 0,02125 & 0,02541 & 0,02640 & 0,13034 & 0,04660 & 0,01513 & 0,03728 & 0,04018 & $-0,01140$ & 0,07502 & 0,04620 \\
\hline Subtotal & 0,03881 & 0,11368 & 0,03471 & 0,29567 & 0,65907 & 0,09460 & 0,03113 & 0,15286 & 0,31932 & 0,02754 & 0,13495 \\
\hline \multicolumn{12}{|l|}{ Females } \\
\hline $\begin{array}{l}\text { Higher } \\
\text { Education }\end{array}$ & 0,02831 & 0,04443 & 0,04711 & 0,13867 & 0,56963 & 0,07827 & 0,00625 & 0,16048 & 0,22290 & 0,05924 & 0,17669 \\
\hline $\begin{array}{l}\text { Secondary } \\
\text { Education } \\
\end{array}$ & 0,02885 & $-0,00401$ & 0,02233 & 0,02486 & 0,00866 & 0,02356 & 0,02157 & 0,02359 & 0,02749 & 0,01242 & 0,01152 \\
\hline subtotal & 0,05716 & 0,04042 & 0,06944 & 0,16353 & 0,57829 & 0,10183 & 0,02781 & 0,18407 & 0,25040 & 0,07165 & 0,18822 \\
\hline $\begin{array}{l}\text { Grand total } \\
\text { (Males \& } \\
\text { Females) }\end{array}$ & 0,09597 & 0,15411 & 0,10415 & 0,45920 & 1,23735 & 0,19644 & 0,05895 & 0,33693 & 0,56972 & 0,09919 & 0,32317 \\
\hline
\end{tabular}

Source:ESYE.

According to the results of the table $6 . b$ the contribution of higher and secondary education as total (of men and women) to economic growth has increased from 0,09597 (which analyses in: 0,03881 of men and 0,05716 of women) in 1995 to 0,32317 (that analyses in: 0,13495 of men and 0,18822 of women) in 2006.

It is worth noting that during the same period (1995-2006) women's higher education contribution to the economic growth is higher than the representative of men.

\section{Conclusions}

The results suggest that the relative contribution of secondary and higher education of men and women to economic growth of Greece has risen during the period 1960-2006, the period before crisis. The findings also indicate that the increased tendency for higher education of women and their consequent rising participation in the labor force have contributed a great deal to the growth process after nineties.

It also worth noted that the empirical evidence of this study is compatible to the corresponding of previous studies. According to these the contribution of higher education is higher when the economic growth rate is also higher and generally the contribution of education is related to the economic growth.

Because of the basic purpose of educational policy that is the increase of higher (mainly) and secondary education's contribution to the economic growth of Greece; it is necessary to investigate in a further study: the parameters which maximize the external efficiency of higher and secondary (especially vocational) education in Greece the period after the global economic crisis of 2008.

Finally by taking into account the Greek exodus of generation $\mathrm{G}$ during the same period, after the global crisis of 2008; it is necessary to investigate in a further study: the effectiveness of 
educational development policy tools such as the HFRI ${ }^{1}$ (Hellenic Foundation of Research and Innovation) which is planned to contribute to the reduction of the tremendous "brain drain" by investing in high quality in research of education.

\section{Acknowledgments}

I express my deep sense of gratitude to prof. K. Prodromidis and G. Psacharopoulos for their comments. Also I would like to express my sincere gratitude to prof. C. Fotakis, Alternate Minister of Research and Innovation, for providing me with data of HFRI.

\section{Literature}

Benhabib, J. \& Spiegel, M. (1994) The role of human capital in economic development, evidence from aggregate cross-country data', Journal of Monetary Economics, 34, 143173.

Blau, F. (1996) Symposium on primary and secondary education, Journal of Economic Perspectives, 10 (4), 3-8.

Bowles, S. (1967) Sources of growth in the Greek Economy, 1951-1961, Center of International Affairs, Memorandum No 27, Cambridge: Harvard University 1967.

Choi, K. (1993) Technological change and educational wage differentials in Korea, Yale University, Economic Growth Center, Center D.P. series No 698.

Denison, E. (1962) The sources of economic growth in the United States and the alternatives before us, New York, Committee for Economic Development.

Grossman, G. \& Helpman, E. (1994) Endogenous innovation in the theory of economic growth, Journal of Economic Perspectives, 8 (1), 23-44.

Juoro, U. (1993) Education, Talent Allocation and Growth in Indonesia, World Bank, mimeo.

Leibenstein, H. (1967) Rates of return to education in Greece, Development Advisory Service, Harvard University, Economic Development Report No 94, Sep. 1967.

Lucas, R. (1988) On the mechanics of economic development, Journal of Monetary Economics, pp. 3 - 42.

Lucas, R. (1990) Why doesn't capital flow from rich to poor countries? American Ecomomic Review, 80 (2), 92-96.

Magoula, T. \& Prodromidis, K. (1999) Education and Economic Growth in Greece, Discussion Paper No. 102, Athens University of Economics and Business.

Magoula, Th. (1998) Education and economic growth: the Greek reality, Athens University of Economics and Business, unpublished Ph.D. thesis.

Mankiw, N., Romer, D. \& Weil, D. (1992) A contribution to the empirics of economic growth, Quarterly Journal of Economics, 107, 407-437.

Mulligan, C. and Sala-i-Martin, X. (1995) Measuring aggregate human capital, NBER Working Paper Series, WP No 5016.

\footnotetext{
${ }^{1}$ HFRI is based on a dynamic mix of local Universities, Research Organizations and private companies, together with mixed public-private funding schemes and technology transfer support services. This growth model is planned to connect geographically and thematically different R\&I strengths of the country into a cohesive network.
} 
Psacharopoulos, G. (1972) The Marginal contribution of Education to Economic Growth, Economic Development and Cultural Change 20, No 4, pp. 641-58

Psacharopoulos, G. (1974) The screening Hypothesis and the returns to Education, Journal of Political Economy 82, No 5.

Psacharopoulos, G. (1975) Earnings of Education in OECD Countries, OECD 1975.

Psacharopoulos, G. (1982) Earnings and Education in Greece, 1960-1977, European Economic Review 17, pp. 333-347.

Psacharopoulos, G. (1982) The economics of higher Education in developing countries, Comparative Education Review, vol. 26, No 2, June 1982.

Psacharopoulos, G. (1987) Economics of Education: Research and Studies, Oxford: Pergamon.

Psacharopoulos, G. (1992) Educational Expansion and Earnings differentials in Greece, Comparative Education Review, vol. 36, No 1.

Psacharopoulos, G. \& Arriagada, A. (1992) The Educational Composition of the Labor Force: An International Update, Journal of Educational Planning and Administration, vol. VI, No 2, April 1992, pp. 141-159.

Psacharopoulos, G. (1993) Returns to Investment in Education: A Global Update, Working papers WPS 1067

Psacharopoulos, G. \& Ng, Y. (1994) Earnings and Education in Latin America, Education Economics 2 (2), pp. 187-207.

Psacharopoulos, G. (1995) The Profitability of Investment in Education: Concepts and Methods, HROVP, World Bank, March 1995.

Psacharopoulos, G. (1995) RR Manual: A programme to estimate the rate of return to investment in Education, HCOVP, World Bank, Dec. 1995.

Romer, P. (1986) Increasing returns and long-run growth, Journal of Political Economy, 94(5), 1002-1037.

Romer, P. (1990) Endogenous technological change, Journal of Political Economy, 98 (5, pt. 2) S71-S102.

Romer, P. (1993) Idea gaps and object gaps in economic development, Journal of Monetary Economics 32, 543-573.

Schultz, T. (1961) Investment in human capital, American Economic Review, 51, 1-17.

Welch, F. (1970) Education in production, Journal of Political Economy, 78, 35-79.

Winter-Ebmer, R. (1992) Endogenous growth, human capital and industry wages, Arbeitspapier No, 9206, Institut fuer Volkswirtschaftslehre, Johannes Kepler Universitaet. 